Uşak Üniversitesi Sosyal Bilimler Dergisi

$2014,7 / 4$

\title{
İlköğretim İngilizce Öğretmenlerinin Öğretmenlik Mesleği Özel Alan Yeterliklerine İlişkin Algılarının Belirlenmesi
}

Sema KARARMAZ

Ali ARSLAN ${ }^{*}$

\section{Özet}

$\mathrm{Bu}$ araştırmanın amacı, ilköğretimde görev yapan İngilizce öğretmelerinin özel alan yeterliklerine yönelik algılarını ve bu algılarının çeşitli değişkenlere göre değişip değişmediğini tespit etmektir. Araştırmada genel tarama modelinden ilişkisel tarama modeli kullanılmıştır. Çalışmanın verileri İngilizce öğretmenliği özel alan yeterlikleri değerlendirme ölçeği ile toplanmıştır. Araştırmanın evrenini Zonguldak merkez ve ilçelerinde devlet ve özel okullarda kadrolu olarak görev yapan 437 İngilizce öğretmeni örneklemini ise 195 İngilizce öğretmeni oluşturmaktadır. Araştırmada elde edilen verilerin çözümlenmesinde frekans, yüzde, aritmetik ortalama, t- testi ve tek yönlü varyans analizi (ANOVA) kullanılmıştır. Çalışmanın sonunda İngilizce öğretmenlerinin özel alan yeterliklerine ilişkin algılarının oldukça yüksek olduğu sonucuna ulaşılmıştır. Öğretmenlerin özel alan yeterliklerine ilişkin yeterlik algılarında hizmet-içi eğitim alma ve kıdem yılı değişkenlerine göre yeterlik alanlarının hiçbirinde anlamlı bir fark bulunmazken; cinsiyet değişkenine göre Dil Becerilerini Geliştirme ve Okul, Aile ve Toplumla İşbirliği Yapma yeterlik alanında kadın öğretmenler lehine; mezun olunan okul türü değişkenine göre Dil Gelişimini İzleme ve Değerlendirme yeterlik alanında eğitim fakültesinden mezun olanlar lehine ve görev yapılan okul türü değişkenine göre DBG yeterlik alanında özel okulda çalışan öğretmenler lehine anlamlı bir fark bulunmuştur. Sonuçlar dikkate alınarak öneriler sunulmuştur.

Anahtar Kelimeler: Öğretmen Yetiştirme, İngilizce Öğretmenliği, Yeterlikler, Özel Alan Yeterlikleri.

\section{Determining The Perceptions of Primary School English Teachers on Subject Area Competencies}

\begin{abstract}
The aim of this study is to determine the self-perceptions of primary school English teachers on subject area competencies and to identify whether they
\end{abstract}

\footnotetext{
* Doç. Dr., Bülent Ecevit Üniversitesi, Ereğli Eğitim Fakültesi, arslan54tr@yahoo.com
} 
differ or not in terms of some variables. In this study causal comparative method was used. The data of study was gathered with help of scale of English teachers about proficiency. The universe of the study includes 437 English teachers and sample of study was 195 English teachers working at state and private schools in the city center and the towns of Zonguldak. Frequency, percentage, mean, t-test and one-way ANOVA were used to analyze the data obtained from the study. According to the findings of the study, the self-perceptions of English teachers on subject area competencies were found quite high. According to seniority and taking an in-service course, no significant difference was found in any of the areas of competencies. According to gender, in Development of Language Skills and Cooperation with the School, Family and Society competency areas, in favor of female teachers; according to university graduation, in Monitoring and Evaluation of Language Development (DGID) competency area, in favor of the graduates of educational faculty and according to the school they are working, in Development of language skills (DBG) competency area, in favor of private school teachers significant differences were found. Based on the results of the study some recommendations were made.

Key Words: English Teacher, Competency, Subject Area Competency, Self-Perception.

\section{Giriş}

Ülkelerin ekonomik, sosyal, kültürel, bilimsel ve teknolojik alanda ilerleyebilmesinde eğitimin çok önemli bir rolü vardır. Eğitim sisteminin uygulayıcısı olan ve programlardaki istendik davranışların öğrencilere etkili bir şekilde kazandırılmasında kilit bir rol üstlenen öğretmenlerdir. Hem toplumsal ilerlemenin öncüsü hem de toplumsal olarak ilerlemeyi sağlayacak olan bireyleri yetiştirmek görevini üstlenen öğretmenlerin bu büyük sorumluluğu yerine getirebilecek niteliklere sahip olmaları gerekmektedir.

Dünyadaki bilim ve teknoloji alanındaki yenilikler ve ilerlemeler eğitim alanında yeniden yapılanmaları zorunlu kılmıştır (Beltekin, 2010). Bilgi çağı ile ortaya çıkan bilgi toplumunun yapısına uygun, bilgiyi arayan, üreten ve kullanabilen nitelikli bireyler yetiştirmek amacıyla eğitim kurumları da programlarını düzenlemek ya da değiştirmek durumunda kalmışlardır (Karaca, 2008). Değişen programlara paralel olarak toplumun beklentilerini karşılayacak eğitimi verecek olan öğretmenlerin de 
niteliklerinin yükseltilmesi, yeterliliklerinin artırılması gerekmektedir (Yeşilyurt, 2011) ve bu daha fazla önem kazanmaktadır. Çünkü öğretmenlik toplumla iç içe olan bir meslektir. Öğretmen ne kadar nitelikli olursa öğretim süreci de o düzeyde etkili ve verimli olacaktır.

1739 sayılı Milli Eğitim Temel Kanunu'nda öğretmen nitelikleri genel hatları ile öğreteceği alanının bilgi ve becerilerine sahip olması, alanının kapsamında yer alan bu bilgi ve becerilerin nasıl öğretileceğine dair bilgi ve becerilere sahip olması ve alanın dışındaki disiplinleri de içine alan genel kültür bilgisine sahip olması olarak belirlenmiştir. Öğretmen yetiştirmede nitelik ve nicelik sorunlarını gidermek için bir takım çalışmalar yapıla gelmiştir. Buna bağlı olarak son yıllarda öğretmen yeterlikleri üzerine ülkemizde bir dizi çalışma yürütülmüştür. İlk olarak MEB ve üniversite temsilcileri tarafından oluşturulan bir komisyon tarafından 1999 yılında eğitme-öğretme yeterlikleri, genel kültür bilgi ve becerileri, özel alan bilgi ve becerileri başlıkları altında öğretmen yeterlikleri belirlenmiştir (MEB, 2002). 2002 yılında yürürlüğe giren bu yeterlikler Öğretmen Yetiştirme ve Eğitimi Genel Müdürlüğü (ÖYEGM) tarafından öğretmen yetiştiren kurumlara gönderilmiş ve öğretmen adaylarının bu yeterliklere sahip olacak şekilde yetiştirilmesini talep etmiştir (Seferoğlu, 2004). 1999'da hazırlanan yeterlikler uygulamaya dönüştürülemeden 2002 yılında $A B$ tarafından desteklenen Temel Eğitime Destek Projesi (TEDP) bünyesinde ÖYEGM tarafından yeni bir çalışma başlatılmıştır. ÖYEGM tarafından hazırlanan öğretmenlik mesleği genel ve özel alan yeterlikleri bu alanda yapılmış ayrıntılı bir çalışma olmuştur. Çalışmanın sonunda öğretmenlik mesleği genel yeterlikleri (MEB, 2006), ve ilköğretim öğretmenlerinin 16 branşı kapsayan özel alan yeterlikleri (MEB, 2008) tamamlanarak yürürlüğe konmuştur. Özel alan yeterlikleri, yeterlik alanı, kapsam, yeterlikler ve performans göstergelerinden oluşmaktadır. İngilizce öğretmeni özel alan yeterlikleri 5 yeterlik alanı, 26 alt yeterlik ve 158 performans göstergesinden oluşmaktadır.

Öğretmenlerin sahip olması gereken genel yeterlikler kişisel ve mesleki değerlere sahip olma ve mesleki gelişimi sağlama, öğrenciyi tanıma ve ona rehberlik etme, öğretme-öğrenme sürecini planlama ve uygulama, öğrencilerin gelişimini izleme ve değerlendirme, okul, aile ve toplum işbirliğini sağlama ve öğreteceği alanla ilgili program ve içerik bilgisine sahip olma yeterliklerini kapsamaktadır (MEB, 2006). Bu yeterliklere paralel olarak İngilizce öğretmenleri için belirlenen özel alt yeterlikler ise Öğretim Süreçlerini Planlama ve Düzenleme (ÖSPD); Dil Becerilerini Geliştirme, Dil Gelişimini İzleme ve Değerlendirme (DGID), Okul, Aile ve Toplumla İşbirliği Yapma (OATIY), Mesleki Gelişimini Sağlama (MGS) şeklinde belirlenmiştir (MEB, 2008). 
Öğrencilerin İngilizce okuryazarllğına sahip olması ve bu dili gereği gibi kullanabilmesinde İngilizce öğretmenlerine büyük rol düşmektedir. Bu nedenle İngilizce öğretmenlerinin öğretmenlik mesleği özel alan yeterliklerine ilişkin algılarını araştırmak önem arz etmektedir. Öğretmenlerin kendilerini yetersiz hissettikleri alanlar tespit edilerek eğitim ihtiyaçları ortaya konulabilir. Bu sayede MEB, bünyelerinde görev yapan öğretmenlerin yeterliklerinin artırmaya dönük hizmetiçi eğitim programları geliştirebilir.

Ülkemizde. Türkiye'de yapılan çalışmalar incelendiğinde İngilizce öğretmenlerinin mesleki özel alan yeterliklerine ilişkin çalışmalar çok sınırlı olduğu, çoğunlukla öğretmen adaylarının yeterlik algılarını belirlemeye dönük yürütüldügüü görülmüştür (Baykara, 2011; Uygur, 2010; Büyükduman, 2006; Çakır ve Alıc1, 2009; Zehir Topkaya ve Yavuz, 2011). İngilizce öğretmenlerinin yeterliğine dönük çalışmalar (Güven, 2005; Tunç yüksel, 2010; Güven ve Çakır, 2012) yapılsa da bu çalışmada onlardan farklı olarak MEB (2008) tarafından belirlenen özel alan yeterliklerinin temele alınarak yürütülmüş olmasıdır.

Öğretmenlere yönelik yapılan her araştırma eğitimde ilerleme adına olumlu etkiye sahiptir ve bu araştırmanın İngilizce öğretmenliği özel alan yeterliklerine yönelik bir farkındalık oluşturarak öğretmen ve öğretmen adaylarının yeterliklerini sorgulamalarını; öğretmen, yönetici, öğretmen yetiştiren kurumlar için öğretim faaliyetlerinde yeni görüş ve öneriler geliştirmelerini, bu yönde çalışmalara ağırlık vermelerini sağlayacağı umut edilmektedir. Ayrıca bu alanda literatüre yeni bir ölçek kazandırarak katkı sağlayacağı da düşünülmektedir.

\section{Problem Cümlesi}

Araştırmanın problem cümlesi “ỉlköğretim (î̈) İngilizce öğretmenlerinin özel alan yeterliklerine (ÖAY) ilişkin algıları cinsiyet, kıdem, mezun olunan okul türü, görev yaptığ 1 okul türü ve hizmet içi eğitim almalarına göre değişmekte midir? şeklindedir.

\section{Alt problemler}

1. İÖ İngilizce öğretmenlerinin özel alan yeterliklerine (ÖAY) ilişkin algıları ne düzeydedir?

2. İÖ İngilizce öğretmenlerinin ÖAY'ne ilişkin algıları cinsiyetlerin göre değişmekte midir?

3. i̇Ö İngilizce öğretmenlerinin ÖAY'ne ilişkin algıları kıdem yılına göre değişmekte midir? 
4. İÖ İngilizce öğretmenlerinin ÖAY'ne ilişkin algıları mezun oldukları okul türüne göre değişmekte midir?

5. İÖ İngilizce öğretmenlerinin ÖAY'ne ilişkin algıları görev yaptıkları okul türüne göre değişmekte midir?

6. İÖ İngilizce öğretmenlerinin ÖAY'ne ilişkin algıları hizmet içi eğitim alma durumlarına göre değişmekte midir?

\section{Yöntem}

Bu bölümde, araştırma modeline, çalışma grubuna, veri toplama aracına ve verilerin analizinde kullanılan istatistiksel yöntemlere ilişkin bilgi verilmiştir.

\section{Araştırma Modeli}

$\mathrm{Bu}$ araştırmada genel tarama modelinden karşılaştırma yolu ile ilişki belirlenmeye çalışılmıştır. Karşılaştırma yolu ile ilişki belirlemede en az iki değişken vardır ve aralarında bir farklılaşma olup olmadığına bakılır (Karasar, 2005). Bu çalışmada da İngilizce öğretmenlerinin özel alan yeterlik algılarının cinsiyetlerine, kıdem yılına, mezun oldukları ve görev yaptıkları okul türü ile hizmet içi eğitim alma durumlarına göre farklılaşma olup olmadığ 1 incelenmiştir.

\section{Evren ve Örneklem}

$\mathrm{Bu}$ araştırmanın evrenini Zonguldak merkez ve ilçelerinde devlet ve özel ilköğretim okullarında kadrolu olarak görev yapmakta olan 437 İngilizce öğretmeni oluşturmuştur. Ölçek küme örnekleme yöntemi kullanılarak 235 İngilizce öğretmenine gönderilmiştir. İnceleme neticesinde uygun şekilde cevaplandırılmadığı tespit edilen ölçekler çıkarılarak 195 öğretmen çalışmaya dahil edilmiştir. Öğretmenlerin \% 74,9'u kadın, \% 25,1'i ise erkektir.

\section{Veri Toplama Araci}

Araştırmanın verileri ÖYEGM tarafından hazırlanan ve TTK başkanlığınca onaylanan "İngilizce Öğretmenliği Özel Alan Yeterlikleri Değerlendirme Ölçeği" ile toplanmıştır. Ölçeğin oluşturulmasına, geçerlik ve güvenirliğine ilişkin bilgiler aşağıda sunulmuştur.

\section{İngilizce Öğretmeni Özel Alan Yeterlikleri Değerlendirme Ölçeği}

MEB ÖYEGM tarafından hazırlanan İngilizce öğretmenliği özel alan yeterlikleri incelenmiştir. 5 yeterlik alanı ve bunlara ilişkin toplam 26 alt yeterlik ele alınarak ve yeterlik ifadelerinin aslını bozmadan çalışmaya uyarlanarak ölçeğin deneme formu oluşturulmuştur. İki bölümden oluşan ölçeğin birinci bölümünde kişisel bilgilere; ikinci bölümünde ise İÖ İngilizce öğretmenlerinin belirlenen özel alan yeterliklerine ilişkin algılarının ortaya konulmasına yönelik 26 maddeye yer verilmiştir. Ölçekte yer alan her 
madde "kesinlikle katilıyorum" (5), “katılıyorum" (4), "kararsızım” (3), "katılmıyorum" (2) ve "kesinlikle katılmıyorum" (1) şeklinde ifade edilen beşli dereceleme ölçeğinde düzenlenmiştir. Ölçekte olumsuz madde yer almamaktadır. Verilerin yorumlanmasında 1.00 - 1.80 arası olanlar (1) "kesinlikle katılmıyorum", 1.81 - 2.60 arası olanlar (2) "katılmiyorum", 2.61 - 3.40 arası olanlar (3) "kararsızım", 3.41 - 4.20 arası olanlar (4) " katıliyorum" ve 4.21-5.00 arası olanlar (5) "kesinlikle katıliyorum" olarak değerlendirilmiştir.

Deneme amaçlı olarak hazırlanan ölçek Zonguldak ili Ereğli ilçesinde görev yapmakta olan 83 ilköğretim İngilizce öğretmenine uygulanmıştır. Pilot çalışma için ön görülen kişi sayısının ölçekte yer alan madde sayısının 2 katından daha fazlasının yeterli olduğu düşünüldüğünde (Klein, 1994) pilot çalışma için seçilen öğretmen sayısının yeterli olduğu söylenilebilir. Ölçeğin yapı geçerliğini ortaya koymak amacıyla her bir madde için madde toplam korelasyonu hesaplanmıştır. Ölçek maddelerinin iç tutarlılığı için ise Cronbach Alpha katsayısı formülü kullanılmıştır. Ölçekte MEB tarafından belirlenen alt yeterliklerin her biri faktör olarak belirlenmiştir.

Tablo 1. Ölçek Faktörlerinin Madde Sayısı, Madde-Toplam Korelasyonları ve Güvenirlik Katsayıları

\begin{tabular}{lccccc}
\hline & ÖSPD & DBG & DGID & OATIY & MGS \\
\hline Madde Sayısı & 5 & 7 & 4 & 6 & 4 \\
\hline Madde-Toplam Korelas & $0,611-0,749$ & $0,566-0,822$ & $0,720-0,848$ & $0,483-0,767$ & $0,704-0,867$ \\
\hline Cronbach Alfa & 0,873 & 0,907 & 0,897 & 0,852 & 0,896 \\
\hline
\end{tabular}

Ölçekte yer alan faktörlerden birincisi Öğretim Süreçlerini Planlama ve Düzenleme (İÖSPD) faktörüdür. Bu faktör toplam 5 maddeden oluşup maddelerin madde toplam korelasyonlarının 0,611 ile 0,749 arasında değiştiği görülmektedir. Bu faktörün Cronbach Alfa iç tutarlık katsayısı 0,873 olarak bulunmuştur. İkinci faktör olan Dil Becerilerini Geliştirme (DBG) faktörü 7 maddeden oluşup maddelerin madde toplam korelasyonlarının 0,566 ile 0,822 arasında değiştiği görülmektedir. Bu faktörün Cronbach Alfa iç tutarlık katsayısı 0,907 olarak bulunmuştur. Üçüncü faktör olan Dil Gelişimini İzleme ve Değerlendirme (DGID) faktörü 4 maddeden oluşup maddelerin madde toplam korelasyonlarının 0,720 ile 0,848 arasında değiştiği görülmektedir. Bu faktörün Cronbach Alfa iç tutarlık katsayısı 0,897 olarak bulunmuştur. Dördüncü faktör olan Okul, Aile ve Toplumla 
İşbirliği Yapma (OAİTY) faktörü 6 maddeden oluşup maddelerin madde toplam korelasyonlarının 0.483 ile 0,767 arasında değiştiği görülmektedir. Bu faktörün Cronbach Alfa iç tutarlık katsayısı 0,852 olarak bulunmuştur. Beşinci faktör olan İngilizce alanındaki Mesleki Gelişimini Sağlama (MGS) faktörü 4 maddeden oluşup maddelerin madde toplam korelasyonlarının 0,704 ile 0,867 arasında değiştiği görülmektedir. Bu faktörün Cronbach Alfa iç tutarlık katsayısı 0,896 olarak bulunmuştur.

Ölçeğin güvenirlik ve geçerlik çalışmasının ardından nihai ölçek ilköğretim İngilizce öğretmenlerinin özel alan yeterliklerine ilişkin algilarının belirlenmesi amacıyla 2012-2013 öğretim yılında Zonguldak ilinde görev yapmakta olan ilköğretim İngilizce öğretmenlerine uygulanmıştır.

\section{Verilerin Analizi}

Ölçeğin ilk bölümünde yer alan kişisel bilgilerin belirlenmesi amacıyla frekans ve yüzde dağılımlarına bakılmıştır. Araştırmanın 1. alt problemi için frekans, yüzde ve ortalama analizleri yapılmıştır. 2., 4., 5. ve 6. alt problemler için bağımsız gruplar için t-test ve 3 . alt problem için tek yönlü varyans analizi (One-way ANOVA) tekniği kullanılmıştır. Verilerin yorumlanması 0,05 anlamlılık düzeyinde yapılmıştır.

\section{Bulgular}

$\mathrm{Bu}$ bölümde araştırmanın amacına uygun olarak elde edilen bulgulara yer verilmiştir.

\section{Birinci Alt Probleme İlişkin Bulgular}

Araştırmanın 1. alt problemine ilişkin bulgular elde edilirken frekans, yüzde, aritmetik ortalama değerleri hesaplanarak aşağıda verilmiştir.

Araştırmada kullanılan ölçekteki 5 yeterlik alanının alt yeterliklerine ilişkin elde edilen yeterlik puanlarının yüzde, frekans ve aritmetik ortalama değerleri tablolar halinde aşağıda verilmiştir. 
İngilizce Öğretim Süreçlerini Planlama ve Düzenleme Yeterlik Alanına İlişkin Algıları

Tablo 2. İngilizce Öğretim Süreçlerini Planlama ve Düzenleme Yeterlik Alanındaki Alt Yeterliklere İlişkin Öğretmen Algıları

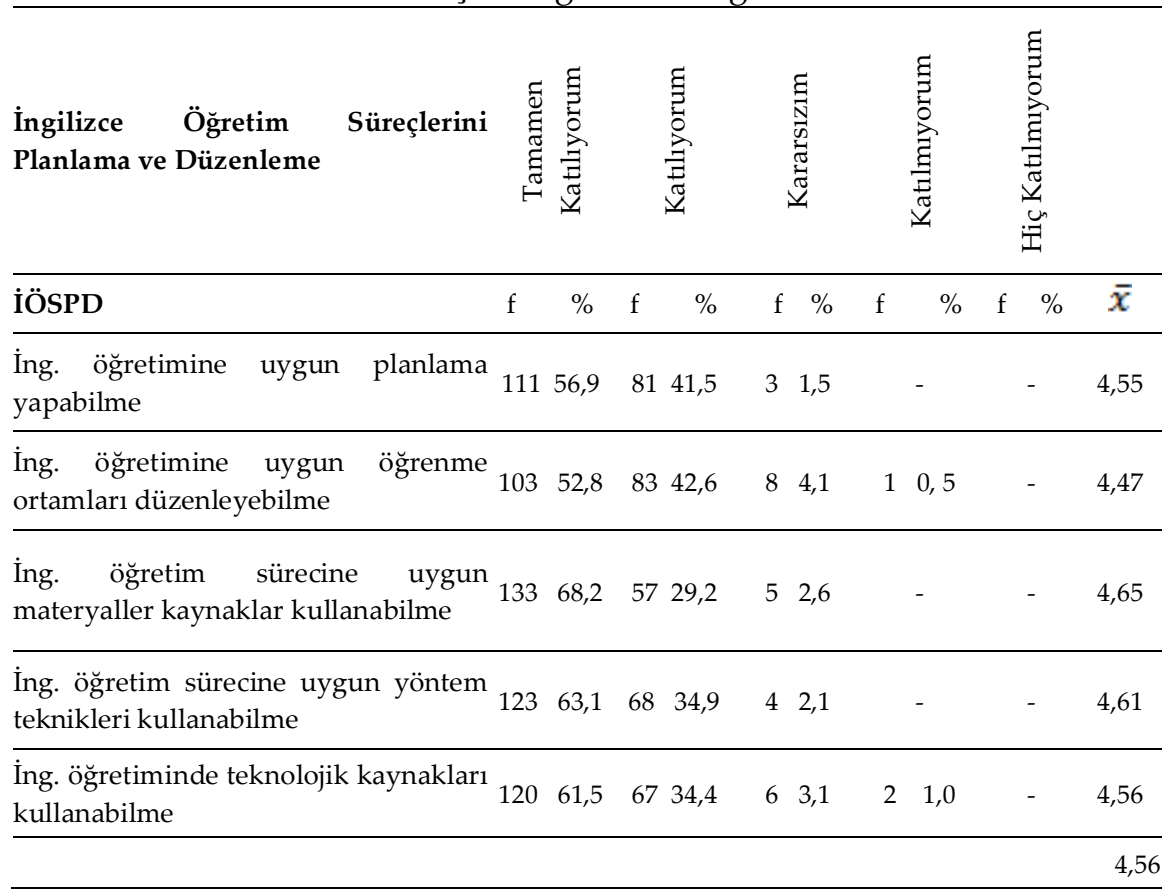

Tablo 2 incelendiğinde "İngilizce öğretimine uygun planlama yapabilirim." alt yeterlik maddesine ilişkin öğretmenlerin $81^{\prime} \mathrm{i}(\% 41,5)$ katıllyorum; 111'i $(\% 56,9)$ tamamen katıliyorum cevabını vermiştir. Öğretmenlerin bu madde için verdikleri yanıtların ortalaması 4,55 'dir. Bu ortalama tamamen katılıyorum aralı̆̆ına denk gelmektedir. Buna göre öğretmenlerin İngilizce öğretimine uygun planlama yapabilme alt yeterliğine ilişkin kendilerini oldukça yeterli olarak algıladıkları söylenebilir.

“İngilizce öğretimine uygun öğrenme ortamları düzenleyebilirim." alt yeterlik maddesine ilişkin öğretmenlerin 83'ü $(\% 42,6)$ katıllyorum; 103'ü $(\% 52,8)$ tamamen katılıyorum cevabını vermiştir. Öğretmenlerin bu madde için verdikleri yanitların ortalaması $4,47^{\prime}$ dir. Bu ortalama tamamen katilıyorum aralığına denk gelmektedir. Buna göre öğretmenlerin İngilizce öğretimine 
uygun öğrenme ortamları düzenleyebilme alt yeterliğine ilişkin kendilerini oldukça yeterli olarak algıladıkları söylenebilir.

"İngilizce öğretim sürecine uygun materyaller ve kaynaklar kullanabilirim." alt yeterlik maddesine ilişkin öğretmenlerin 133'ü $(\% 68,2)$ tamamen katılıyorum cevabını vermiştir. Öğretmenlerin bu madde için verdikleri yantların ortalaması 4,65'dir. Bu ortalama tamamen katilıyorum aralığına denk gelmektedir. Buna göre öğretmenlerin İngilizce öğretim sürecine uygun materyal ve kaynak kullanabilme alt yeterliğine ilişkin kendilerini oldukça yeterli olarak algıladıkları söylenebilir.

“İngilizce öğretim sürecine uygun yöntem teknikleri kullanabilirim.” alt yeterlik maddesine ilişkin öğretmenlerin 123'ü $(\% 63,1)$ tamamen katıliyorum cevabını vermiştir. Öğretmenlerin bu madde için verdikleri yanıtların ortalaması 4,61'dir. $\mathrm{Bu}$ ortalama tamamen katılıyorum aralığına denk gelmektedir. Buna göre öğretmenlerin öğretim sürecine uygun yöntem ve teknikler kullanabilme alt yeterliğine ilişkin kendilerini oldukça yeterli olarak algıladıkları söylenebilir.

“İngilizce öğretiminde teknolojik kaynakları kullanabilirim." alt yeterlik maddesine ilişkin öğretmenlerin 67'si $(\% 34,4)$ katılıyorum; 120'si $(\% 61,5)$ tamamen katıllyorum cevabını vermiştir. Öğretmenlerin bu madde için verdikleri yanitların ortalaması $4,56^{\prime}$ dır. Bu ortalama tamamen katiliyorum aralığına denk gelmektedir. Buna göre öğretmenlerin İngilizce öğretiminde teknolojik kaynakları kullanabilme alt yeterliğine ilişkin kendilerini oldukça yeterli olarak algıladıkları söylenebilir.

Sonuç olarak IOÖSPD yeterlik alanındaki alt yeterlilikler incelendiğinde yeterlik algıları bakımından öğretmenler $\bar{x}=4,56$ genel ortalamayla tamamen katılıyorum aralığında yüksek düzeyde IÖSPD yeterliğine sahip olduklarını belirtmişlerdir. 
Dil Becerilerini Geliştirme Yeterlik Alanına İlişkin Algıları

Tablo 3. Dil Becerilerini Geliştirme Yeterlik Alanındaki Alt Yeterliklere İlişkin Öğretmen Algıları

Dil Becerilerini Geliştirme

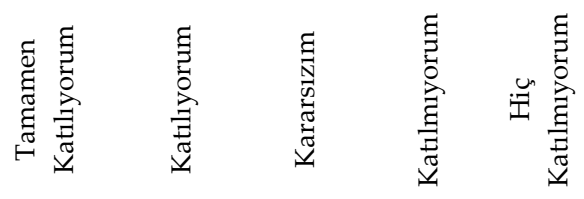

\begin{tabular}{|c|c|c|c|c|c|c|c|c|c|c|}
\hline & $\mathrm{f}$ & $\%$ & $\mathrm{f}$ & $\%$ & $\mathrm{f}$ & $\%$ & $\mathrm{f}$ & $\%$ & $\mathrm{f} \quad \%$ & $\bar{x}$ \\
\hline 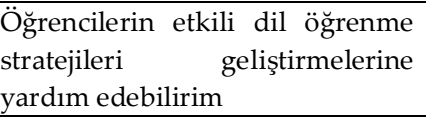 & 78 & 40,0 & 107 & 54,9 & 10 & 5,1 & & - & - & 4,34 \\
\hline $\begin{array}{l}\text { Öğrencilerin } \begin{array}{r}\text { İngilizceyi doğru, } \\
\text { kullanmalarını }\end{array} \\
\text { anlaşılır } \\
\text { sağlayabilirim. }\end{array}$ & 91 & 46,7 & 89 & 45,6 & 12 & 6,2 & 3 & 1,5 & - & 4,47 \\
\hline $\begin{array}{l}\text { Öğrencilerin dinleme/izleme } \\
\text { becerilerini geliştirebilirim. }\end{array}$ & 71 & 36,4 & 102 & 52,3 & 18 & 9,2 & 4 & 2,1 & - & 4,23 \\
\hline $\begin{array}{l}\text { Öğrencilerim } \\
\text { becerilerini geliştirebilirim. }\end{array}$ & 52 & 26,7 & 104 & 53,3 & 291 & & & 4,6 & 10,5 & 4,01 \\
\hline $\begin{array}{l}\text { Öğrencilerin okuma becerilerini } \\
\text { geliştirebilirim. }\end{array}$ & 88 & 45,1 & 91 & 46,7 & 15 & & 1 & 0,5 & - & 4,36 \\
\hline $\begin{array}{l}\text { Öğrencilerin yazma becerilerini } \\
\text { geliştirebilirim. }\end{array}$ & 81 & 41,5 & 82 & 42,1 & 271 & 13,8 & 4 & 2,1 & 10,5 & 4,22 \\
\hline 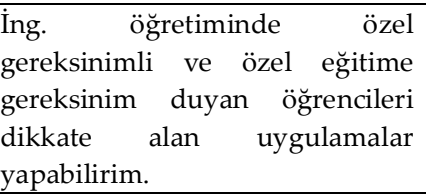 & 25 & 12,8 & 76 & 39,0 & 653 & 33,3 & 23 & 11,8 & 63,1 & 3,46 \\
\hline
\end{tabular}

Tablo 3 incelendiğinde "Öğrencilerin etkili dil öğrenme stratejileri geliştirmelerine yardım edebilirim." alt yeterlik maddesine ilişkin öğretmenlerin 107'si $(\% 54,9)$ katılıyorum; 78'si $(\% 40,0)$ tamamen katıllyorum cevabını vermiştir. Öğretmenlerin bu madde için verdikleri yanıtların ortalaması 4,34'dür. Bu ortalama tamamen katılıyorum aralığına denk gelmektedir. Buna göre öğretmenlerin öğrencilerin etkili dil öğrenme stratejileri geliştirmelerine yardım edebilme alt yeterliğine ilişkin kendilerini oldukça yeterli olarak algıladıkları söylenebilir. 
“Öğrencilerin İngilizceyi doğru, anlaşılır bir şekilde kullanmalarını sağlayabilirim." alt yeterlik maddesine ilişkin öğretmenlerin 89'u $(\% 45,6)$ katılıyorum; 91'i $(\% 46,7)$ tamamen katılıyorum cevabını vermiştir. Öğretmenlerin bu madde için verdikleri yanıtların ortalaması $4,47^{\prime}$ dır. Bu ortalama tamamen katılıyorum aralığına denk gelmektedir. Buna göre öğretmenlerin öğrencilerin İngilizceyi doğru, anlaşılır bir şekilde kullanmalarını sağlayabilme alt yeterliğine ilişkin kendilerini oldukça yeterli olarak algıladıkları söylenebilir.

"Öğrencilerin dinleme/izleme becerilerini geliştirebilirim." alt yeterlik maddesine ilişkin öğretmenlerin 102'si (\%52,3) katıllyorum; 71'i $(\% 36,4)$ tamamen katılıyorum cevabını vermiştir. Öğretmenlerin bu madde için verdikleri yanıtların ortalaması $4,23^{\prime}$ tür. Bu ortalama tamamen katılıyorum aralığına denk gelmektedir. Buna göre öğretmenlerin öğrencilerin dinleme/izleme becerilerini geliştirebilme alt yeterliğine ilişkin kendilerini oldukça yeterli olarak algıladıkları söylenebilir.

“Öğrencilerin konuşma becerilerini geliştirebilirim." alt yeterlik maddesine ilişkin öğretmenlerin 104'ü $(\% 53,3)$ katıllyorum; 52'si $(\% 26,7)$ tamamen katılıyorum cevabını vermiştir. Öğretmenlerin bu madde için verdikleri yanıtların ortalaması 4,01'dir. Bu ortalama katılıyorum aralığına denk gelmektedir. Buna göre öğretmenlerin öğrencilerin konuşma becerilerini geliştirebilme alt yeterliğine ilişkin kendilerini oldukça yeterli olarak algıladıkları söylenebilir.

"Öğrencilerin okuma becerilerini geliştirebilirim." alt yeterlik maddesine ilişkin öğretmenlerin 91'i (\%46,7) katılıyorum; 88'i (\%45,1) tamamen katılıyorum cevabını vermiştir. Öğretmenlerin bu madde için verdikleri yanıtların ortalaması 4,36'dır. Bu ortalama tamamen katılıyorum aralığına denk gelmektedir. Buna göre öğretmenlerin öğrencilerin okuma becerilerini geliştirebilme alt yeterliğine ilişkin kendilerini oldukça yeterli olarak algıladıkları söylenebilir.

"Öğrencilerin yazma becerilerini geliştirebilirim." alt yeterlik maddesine ilişkin öğretmenlerin 82'si (\%42,1) katıllyorum; 81'i (\%41,5) tamamen katılıyorum cevabını vermiştir. Öğretmenlerin bu madde için verdikleri yanitların ortalaması 4,22 'dir. Bu ortalama tamamen katılıyorum aralığına denk gelmektedir. Buna göre öğretmenlerin öğrencilerin yazma becerilerini geliştirebilme alt yeterliğine ilişkin kendilerini oldukça yeterli olarak algıladıkları söylenebilir.

"İngilizce öğretiminde özel gereksinimli ve özel eğitime gereksinim duyan öğrencileri dikkate alan uygulamalar yapabilirim." alt yeterlik maddesine ilişkin öğretmenlerin 65'i $(\% 33,3)$ kararsızım; 76's1 $(\% 39,0)$ katılıyorum; 65'i $(\% 33,3)$ kararsızım cevabını vermiştir. Öğretmenlerin bu 
madde için verdikleri yanıtların ortalaması 3,46'dir. Bu ortalama katılıyorum aralığına denk gelmektedir. Buna göre öğretmenlerin İngilizce öğretiminde özel gereksinimli ve özel eğitime gereksinim duyan öğrencileri dikkate alan uygulamalar yapabilme alt yeterliğine ilişkin kendilerini yeterli olarak algıladıkları söylenebilir. Ancak öğretmenlerin bu maddeye ilişkin yeterlik algıları ortalaması diğer alt yeterlik maddelerinin ortalamalarından daha düşüktür. Bu durumun nedeni İngilizce öğretmenlerinin bu konuda yeterli bilgiye sahip olmamaları olabilir. Ayrıca kalabalık sınıf ortamında bu tür öğrencilerle özel olarak ilgilenmek zor olabilir.

Sonuç olarak DBG yeterlik alanına ait alt yeterlikler incelendiğinde yeterlik algıları bakımından öğretmenler $\bar{x}=4,15$ genel ortalamayla katılıyorum aralığında yüksek düzeyde DBG yeterliğine sahip olduklarını belirtmişlerdir.

Dil Gelişimini İzleme ve Değerlendirme Yeterlik Alanına İlişkin Algıları

Tablo 4. Dil Gelişimini İzleme ve Değerlendirme Yeterlik Alanındaki Alt Yeterliklere İlişkin Öğretmen Algıları

\begin{tabular}{|c|c|c|c|c|c|c|c|c|c|c|}
\hline $\begin{array}{l}\text { Dil Gelişimi Izleme ve } \\
\text { Değerlendirme }\end{array}$ & 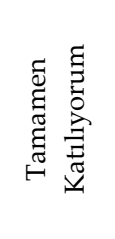 & & 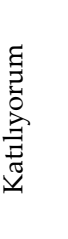 & & 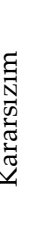 & & 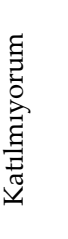 & & 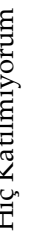 & \\
\hline & $\%$ & $\mathrm{f}$ & $\%$ & $\mathrm{f}$ & $\%$ & $\mathrm{f}$ & $\%$ & $\mathrm{f}$ & $\%$ & $\bar{x}$ \\
\hline $\begin{array}{l}\text { İng. öğretimine ilişkin ölçme ve } \\
\text { değerlendirme uygulamalarının } \\
\text { amaçlarını belirleyebilirim. }\end{array}$ & 9347,7 & 88 & 45,1 & 14 & 7,2 & & - & & - & 4,40 \\
\hline $\begin{array}{lcc}\text { İng. Öğretiminde } & \text { ölçme } & \text { ve } \\
\text { değerlendirme } & \text { araç } & \text { ve } \\
\text { yöntemlerini kullanabilirim. } & \\
\end{array}$ & 10553,8 & 83 & 42,6 & 7 & 3,6 & & - & & - & 4,50 \\
\hline $\begin{array}{l}\text { Öğrencilerin } \text { dil gelişimlerini } \\
\text { belirlemeye } \\
\text { sonuçlarınılik youlçme } \\
\text { gerumlayabilir ve } \\
\text { gerildirim sağlayabilirim. }\end{array}$ & 9548,7 & 87 & 44,6 & 13 & 6,7 & & - & & - & 4,42 \\
\hline $\begin{array}{lcr}\text { Öğrencilerin } & \text { dil gelişimlerini } \\
\text { belirlemeye } & \text { yönelik } & \text { ölçme } \\
\text { değerlendirme } & \text { sonuçlarını } \\
\text { uygulamalarıma yansıtabilirim. }\end{array}$ & 8644,1 & 93 & 47,7 & 14 & 7,2 & & 1,0 & & - & 4,34 \\
\hline
\end{tabular}


Tablo 4 incelendiğinde "İngilizce öğretimine ilişkin ölçme ve değerlendirme uygulamalarının amaçlarını belirleyebilirim." alt yeterlik maddesine ilişkin öğretmenlerin 88'si (\%45,1) katılıyorum; 93'ü $(\% 40,0)$ tamamen katılıyorum cevabını vermiştir. Öğretmenlerin bu madde için verdikleri yanitların ortalaması 4,40'tır. Bu ortalama tamamen katılıyorum aralığına denk gelmektedir. Buna göre öğretmenlerin İngilizce öğretimine ilişkin ölçme ve değerlendirme uygulamalarının amaçlarını belirleyebilme alt yeterliğine ilişkin kendilerini oldukça yeterli olarak algıladıkları söylenebilir.

“İngilizce öğretiminde ölçme ve değerlendirme araç ve yöntemlerini kullanabilirim." alt yeterlik maddesine ilişkin öğretmenlerin 83'ü $(\% 42,6)$ katıllyorum; 105'i $(\% 53,8)$ tamamen katıllyorum cevabını vermiştir. Öğretmenlerin bu madde için verdikleri yantların ortalaması 4,50'dir. Bu ortalama tamamen katılıyorum aralığına denk gelmektedir. Buna göre öğretmenlerin İngilizce öğretiminde ölçme ve değerlendirme araç ve yöntemlerini kullanabilme alt yeterliğine ilişkin kendilerini oldukça yeterli olarak algıladıkları söylenebilir.

“Öğrencilerin dil gelişimlerini belirlemeye yönelik ölçme sonuçlarını yorumlayabilir ve geri bildirim sağlayabilirim." alt yeterlik maddesine ilişkin öğretmenlerin 87'si $(\% 44,6)$ katılıyorum; 86's1 (\%44,1) tamamen katılıyorum cevabını vermiştir. Öğretmenlerin bu madde için verdikleri yanıtların ortalaması 4,42 'dir. Bu ortalama tamamen katılıyorum aralığına denk gelmektedir. Buna göre öğretmenlerin öğrencilerin dil gelişimlerini belirlemeye yönelik ölçme sonuçlarını yorumlayabilme ve geri bildirim sağlayabilme alt yeterliğine ilişkin kendilerini oldukça yeterli olarak algıladıkları söylenebilir.

"Öğrencilerin dil gelişimlerini belirlemeye yönelik ölçme değerlendirme sonuçlarını uygulamalarıma yansıtabilirim." alt yeterlik maddesine ilişkin öğretmenlerin 93'ü (\%47,7) katılıyorum; 86'sı (\%44,1) tamamen katılıyorum cevabını vermiştir. Öğretmenlerin bu madde için verdikleri yanıtların ortalaması 4,34'tür. Bu ortalama tamamen katıliyorum aralığına denk gelmektedir. Buna göre öğretmenlerin öğrencilerin dil gelişimlerini belirlemeye yönelik ölçme değerlendirme sonuçlarını uygulamalarına yansitabilme alt yeterliğine ilişkin kendilerini oldukça yeterli olarak algıladıkları söylenebilir

Sonuç olarak DGID yeterlik alanına ait alt yeterlikleri incelendiğinde yeterlik algıları bakımından öğretmenler $\bar{x}=4,41$ genel tamamen katılıyorum aralığında yüksek düzeyde DGID yeterliğine sahip olduklarını belirtmişlerdir. 
Okul Aile ve Toplumla İşbirliği Yapma Yeterlik Alanına İlişkin Algıları

Tablo 5. Okul Aile Ve Toplumla İşbirliği Yapma Yeterlik Alanındaki Alt Yeterliklere İlişkin Öğretmen Algıları

\begin{tabular}{|c|c|c|c|c|c|c|c|c|c|c|c|c|}
\hline & $\begin{array}{l}\text { Okul Aile ve Toplumla İşbirliği } \\
\text { Yapma }\end{array}$ & & $\underset{\Xi}{\Xi}$ & & 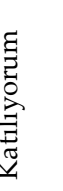 & & 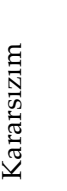 & & 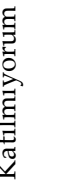 & & 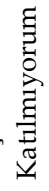 & \\
\hline & & $\mathrm{f}$ & $\%$ & $\mathrm{f}$ & $\%$ & $\mathrm{f}$ & $\%$ & $\mathrm{f}$ & $\%$ & $\mathrm{f}$ & $\%$ & $\bar{X}$ \\
\hline 1. & $\begin{array}{l}\text { Öğrencilerin dil becerilerinin } \\
\text { geliştirilmesinde ailelerle iş } \\
\text { birliği yapabilirim. }\end{array}$ & 60 & 30,8 & 98 & 50,3 & 31 & 15,9 & 6 & 3,1 & & - & 4,08 \\
\hline 2. & $\begin{array}{l}\text { Öğrencilerin yabancı dil } \\
\text { kullanmanın } \\
\text { kavramalarında ilgili kurum, } \\
\text { kuruluş ve kişilerle iş birliği } \\
\text { yapabilirim. }\end{array}$ & 52 & 26,7 & 99 & 50,8 & 38 & 19,5 & 6 & 3,1 & & - & 4,01 \\
\hline 3. & $\begin{array}{l}\text { Öğrencilerin ulusal bayram ve } \\
\text { törenlerin anlam ve öneminin } \\
\text { farkına varmalarını ve aktif } \\
\text { katılımlarını sağlayabilirim. }\end{array}$ & 71 & 36,4 & 100 & 51,3 & 21 & 10,8 & 3 & 1,5 & & - & 4,22 \\
\hline 4. & $\begin{array}{l}\text { Ulusal bayram ve törenlerin } \\
\text { yönetim ve organizasyonunu } \\
\text { yapabilirim. }\end{array}$ & 37 & 19,0 & 83 & 42,6 & 54 & 27,7 & 16 & 8,2 & 5 & 2,6 & 3,67 \\
\hline 5. & $\begin{array}{l}\text { Okulun kültür ve öğrenme } \\
\text { merkezi haline getirilmesinde } \\
\text { toplumla iş birliği yapabilirim. }\end{array}$ & 46 & 23,6 & 110 & 56,4 & 32 & 16,4 & 6 & 3,1 & 1 & 0,5 & 3,99 \\
\hline 6. & Toplumsal liderlik yapabilirim. & 32 & 16,4 & 84 & 43,1 & 62 & 31,8 & 16 & 8,2 & 1 & 0,5 & 3,66 \\
\hline \multicolumn{2}{|c|}{ Genel ortalama } & & & & & & & & & & & 3,93 \\
\hline
\end{tabular}

Tablo 5 incelendiğinde "Öğrencilerin dil becerilerinin geliştirilmesinde ailelerle işbirliği yapabilirim" maddesine öğretmenlerin 98'i $(\% 50,3)$ katılıyorum cevabını vermiştir. Öğretmenlerin bu madde için verdikleri yanıtların ortalaması 4,08'dir. Bu ortalama katılıyorum aralığına denk gelmektedir. Buna göre öğretmenlerin öğrencilerin dil becerilerinin geliştirilmesinde ailelerle işbirliği yapabilme alt yeterliğine ilişkin kendilerini yeterli olarak algıladıkları söylenebilir.

"Öğrencilerin yabancı dil kullanmanın önemini kavramalarında ilgili kurum, kuruluş ve kişilerle işbirliği yapabilirim." alt yeterlik maddesine ilişkin öğretmenlerin 99'u $(\% 50,8)$ katılıyorum cevabını vermiştir. 
Öğretmenlerin bu madde için verdikleri yanttların ortalaması 4,01'dir. Bu ortalama katılıyorum aralığına denk gelmektedir. Buna göre öğretmenlerin öğrencilerin yabancı dil kullanmanın önemini kavramalarında ilgili kurum, kuruluş ve kişilerle işbirliği yapabilme alt yeterliğine ilişkin kendilerini yeterli olarak algıladıkları söylenebilir.

"Öğrencilerin ulusal bayram ve törenlerin anlam ve öneminin farkına varmalarını ve aktif katılımlarını sağlayabilirim." alt yeterlik maddesine ilişkin öğretmenlerin 100'ü $(\% 51,3)$ katılıyorum cevabını vermiştir. Öğretmenlerin bu madde için verdikleri yanıtların ortalaması 4,22'dir. Bu ortalama tamamen katılıyorum aralığına denk gelmektedir. Buna göre öğretmenlerin öğrencilerin ulusal bayram ve törenlerin anlam ve öneminin farkına varmalarını ve aktif katılımlarını sağlayabilme alt yeterliğine ilişkin kendilerini oldukça yeterli olarak algıladıkları söylenebilir.

"Ulusal bayram ve törenlerin yönetim ve organizasyonunu yapabilirim." alt yeterlik maddesine ilişkin öğretmenlerin 83'ü $(\% 42,6)$ katılıyorum cevabını vermiştir. Öğretmenlerin bu madde için verdikleri yanitların ortalaması 3,67'dir. Bu ortalama katılıyorum aralığına denk gelmektedir. Buna göre öğretmenlerin ulusal bayram ve törenlerin yönetim ve organizasyonunu yapabilme alt yeterliğine ilişkin kendilerini yeterli olarak algıladıkları söylenebilir.

"Okulun kültür ve öğrenme merkezi haline getirilmesinde toplumla işbirliği yapabilirim." alt yeterlik maddesine ilişkin öğretmenlerin $110^{\prime} \mathrm{u}$ $(\% 56,4)$ katılıyorum cevabını vermiştir. Öğretmenlerin bu madde için verdikleri yanıtların ortalaması 3,99'dur. Bu ortalama katılıyorum aralığına denk gelmektedir. Buna göre öğretmenlerin okulun kültür ve öğrenme merkezi haline getirilmesinde toplumla işbirliği yapabilme alt yeterliğine ilişkin kendilerini yeterli olarak algıladıkları söylenebilir.

"Toplumsal liderlik yapabilirim." alt yeterlik maddesine ilişkin öğretmenlerin $84^{\prime} \ddot{\mathrm{u}}(\% 43,1)$ katılıyorum cevabını vermiştir. Öğretmenlerin bu madde için verdikleri yantların ortalaması 3,66'dır. Bu ortalama katılıyorum aralığına denk gelmektedir. Buna göre öğretmenlerin toplumsal liderlik yapabilme alt yeterliğine ilişkin kendilerini yeterli olarak algıladıkları söylenebilir.

Sonuç olarak OATIY yeterlik alanına ait alt yeterlikleri incelendiğinde yeterlik algıları bakımından öğretmenler $\bar{x}=3,93$ genel ortalamayla katılıyorum aralığında yüksek düzeyde OATIY yeterliğine sahip olduklarını belirtmişlerdir. 
İngilizce Alanında Mesleki Gelişimini Sağlama Yeterlik Alanına İlişkin Algıları

Tablo 6. İngilizce Alanında Mesleki Gelişimini Sağlama Yeterlik Alanındaki Alt Yeterliklere İlişkin Öğretmen Algıları

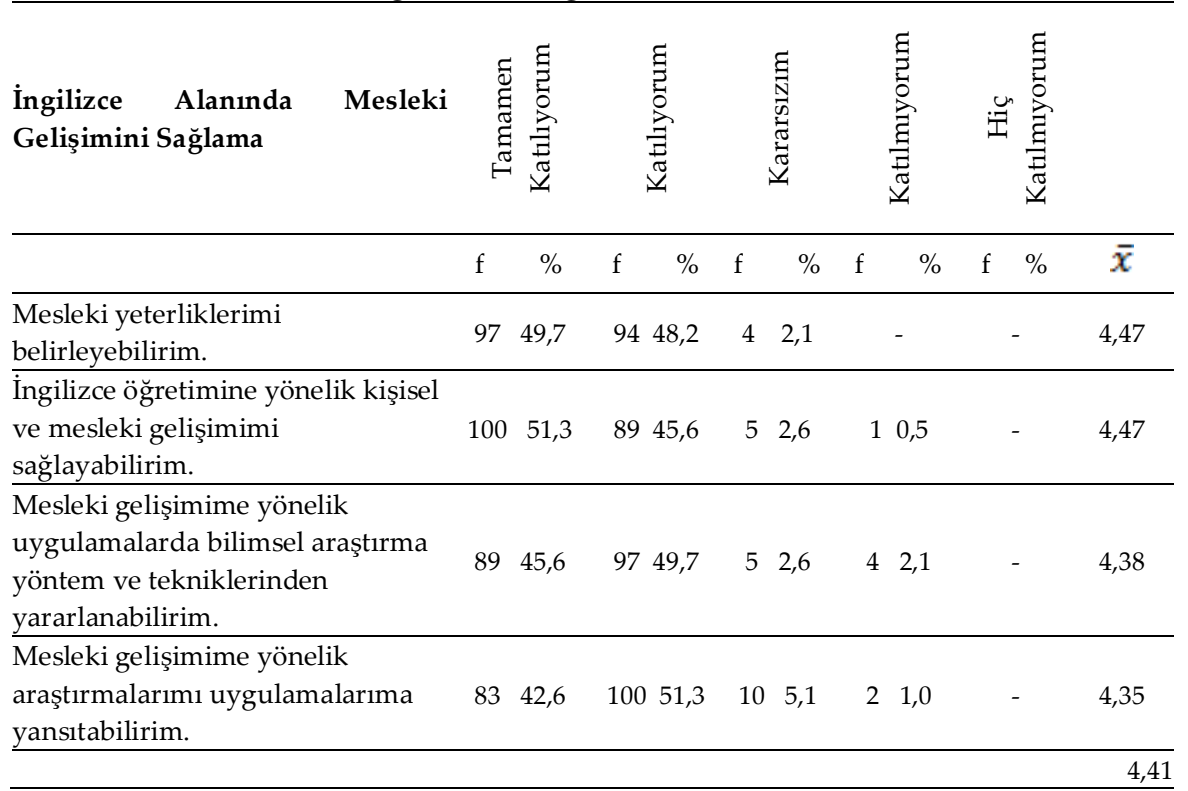

Tablo 6 incelendiğinde "Mesleki yeterliklerimi belirleyebilirim" alt yeterlik maddesine öğretmenlerin 94'ü $(\% 48,2)$ katılıyorum, 97'si $(\% 49,7)$ tamamen katılıyorum cevabını vermiştir. Öğretmenlerin bu madde için verdikleri yanitların ortalaması $4,47^{\prime}$ dir. Bu ortalama tamamen katıliyorum aralığına denk gelmektedir. Buna göre öğretmenlerin mesleki yeterliklerini belirleyebilme alt yeterliğine ilişkin kendilerini oldukça yeterli olarak algıladıkları söylenebilir.

“İngilizce öğretimine yönelik kişisel ve mesleki gelişimimi sağlayabilirim" alt yeterlik maddesine ilişkin öğretmenlerin 89'u $(\% 45,6)$ katılıyorum, 100'ü $(\% 51,3)$ tamamen katılıyorum cevabını vermiştir. Öğretmenlerin bu madde için verdikleri yanıtların ortalaması 4,47'dir. Bu ortalama tamamen katılıyorum aralığına denk gelmektedir. Buna göre öğretmenlerin İngilizce öğretimine yönelik kişisel ve mesleki gelişimini sağlayabilme alt yeterliğine ilişkin kendilerini oldukça yeterli olarak algıladıkları söylenebilir. 
"Mesleki gelişimime yönelik uygulamalarda bilimsel araştırma yöntem ve tekniklerinden yararlanabilirim" alt yeterlik maddesine ilişkin öğretmenlerin 97'si $(\% 49,7)$ katıllyorum, 89'u $(\% 45,6)$ tamamen katılıyorum cevabını vermiştir. Öğretmenlerin bu madde için verdikleri yanıtların ortalaması 4,38'dir. $\mathrm{Bu}$ ortalama tamamen katılıyorum aralığına denk gelmektedir. Buna göre öğretmenlerin mesleki gelişimine yönelik uygulamalarda bilimsel araştırma yöntem ve tekniklerinden yararlanabilme alt yeterliğine ilişkin kendilerini oldukça yeterli olarak algıladıkları söylenebilir.

"Mesleki gelişimime yönelik araştırmalarımı uygulamalarıma yansitabilirim" alt yeterlik maddesine ilişkin öğretmenlerin 100'ü (\%51,3) katılıyorum, 83'ü $(\% 42,6)$ tamamen katıllyorum cevabını vermiştir. Öğretmenlerin bu madde için verdikleri yanıtların ortalaması 4,35'tir. Bu ortalama tamamen katılıyorum aralığına denk gelmektedir. Buna göre öğretmenlerin mesleki gelişimine yönelik araştırmalarını uygulamalarına yansıtabilme alt yeterliğine ilişkin kendilerini oldukça yeterli olarak algıladıkları söylenebilir.

Sonuç olarak İngilizce alanında MGS yeterlik alanına ait alt yeterlilikler incelendiğinde yeterlik algıları bakımından öğretmenler $\bar{x}=4,41$ genel ortalamayla tamamen katılıyorum aralı̆̆ında yüksek düzeyde MGS yeterliğine sahip olduklarını belirtmişlerdir.

\section{Íkinci Alt Probleme İlişkin Bulgular}

Araştırmanın 2. alt problemine ilişkin bulgular elde edilirken verilere bağımsız gruplar için t-test'i yapılmıştır; sonuçlar Tablo $7^{\prime}$ de sunulmuştur.

Tablo 7. Cinsiyete Göre Öğretmen Yeterlik Algılarının Karşılaştırılması

\begin{tabular}{|c|c|c|c|c|c|c|c|c|}
\hline Yeterlik Alanı & Cinsiyet & $\mathbf{N}$ & $\bar{x}$ & Ss & $S d$ & $t$ & $\mathbf{p}$ & Fark \\
\hline \multirow[t]{2}{*}{ İÖSPD } & Erkek & 49 & 4,551 & 0,411 & \multirow{2}{*}{193} & \multirow{2}{*}{0,384} & \multirow{2}{*}{0,701} & \\
\hline & Kadın & 146 & 4,579 & 0,460 & & & & \\
\hline \multirow[t]{2}{*}{ DBG } & Erkek & 49 & 3,959 & 0,532 & \multirow{2}{*}{193} & \multirow{2}{*}{2,793} & \multirow{2}{*}{$0,006^{*}$} & \multirow{2}{*}{ Kadın öğrt. lehine } \\
\hline & Kadın & 146 & 4,207 & 0,540 & & & & \\
\hline \multirow[t]{2}{*}{ DGİD } & Erkek & 49 & 4,326 & 0,564 & \multirow{2}{*}{193} & \multirow{2}{*}{1,421} & \multirow{2}{*}{0,157} & \\
\hline & Kadın & 146 & 4,450 & 0,514 & & & & \\
\hline \multirow[t]{2}{*}{ OATIY } & Erkek & 49 & 3,802 & 0,516 & \multirow{2}{*}{193} & \multirow{2}{*}{2,055} & \multirow{2}{*}{$0,041^{*}$} & \multirow{2}{*}{ Kadın öğrt. lehine } \\
\hline & Kadın & 146 & 3,989 & 0,562 & & & & \\
\hline \multirow[t]{2}{*}{ MGS } & Erkek & 49 & 4,321 & 0,481 & \multirow{2}{*}{193} & \multirow{2}{*}{1,657} & \multirow{2}{*}{0,099} & \\
\hline & Kadın & 146 & 4,458 & 0,509 & & & & \\
\hline
\end{tabular}


Tablo 7 incelendiğinde öğretmenlerin özel alan yeterliklerinin cinsiyete göre farklılaşıp farklılaşmadığını belirlemek amacı ile yapılan analizler sonucunda;

Kadın öğretmenlerin yeterlik algılarının erkek öğretmenlerden ölçeğin genelinde daha yüksek çıkmıştır. Bu duruma ilişkin olarak Çapri ve Çelikkaleli (2008) özellikle toplum tarafından kız çocuklarına daha çok öğretmenlik mesleğinin yakıştırılması ve bu doğrultuda telkinlerde bulunulması, kı öğretmen adaylarının öğretmenliğe ilişkin olumlu tutumlarının erkek öğretmen adaylarına göre daha yüksek olmasının nedeni olarak belirtir. Araştırmanın bulgularına göre İÖSPD, DGID, MGS yeterlik alanlarına ilişkin kadın öğretmenler ile erkek öğretmenlerin ortalamaları arasındaki farkın anlamlı olmadığı görülmekteyken; DBG ve OATIYY yeterlik alanlarına ilişkin ortalamalar arasında cinsiyete göre kadın öğretmenler lehine anlamlı bir farklılık görülmektedir. Sünbül ve Arslan (2009) kişilerarası ilişkilerde bayanların erkeklerden daha yüksek düzeyde sosyal beceri davranışları sergilediklerini ifade etmiştir. Bu sonuçlar OAİTY ve DBG yeterlik alanlarında kadın öğretmenler lehine ortaya çıkan farklılığı açıklayabilir.

\section{Üçüncü Alt Probleme İlişkin Bulgular}

Araştırmanın 3. alt problemine ilişkin bulgular elde edilirken veriler tek yönlü varyans analizi (ANOVA) tekniği ile incelenmiştir. Sonuçlar Tablo 8 'de sunulmuştur.

Tablo 8. Kıdeme Göre Öğretmenlerin Yeterlik Algılarının Karşılaştırılması

\begin{tabular}{|c|c|c|c|c|c|c|}
\hline Yeterlik Alanı & Kidem Y11 & $\mathbf{N}$ & $\bar{x}$ & Ss & F & I \\
\hline \multirow{3}{*}{ İÖSPD } & $1-5$ y1l & 65 & 4,575 & 0,438 & \multirow{3}{*}{0,186} & \multirow{3}{*}{0,831} \\
\hline & 6-14 y1l & 95 & 4,585 & 0,456 & & \\
\hline & 15-üstü & 35 & 4,531 & 0,449 & & \\
\hline \multirow{3}{*}{ DBG } & $1-5$ y1l & 65 & 4,208 & 0,551 & \multirow{3}{*}{0,695} & \multirow{3}{*}{0,500} \\
\hline & 6-14 yll & 95 & 4,105 & 0,535 & & \\
\hline & 15-üstü & 35 & 4,134 & 0,577 & & \\
\hline \multirow{3}{*}{ DGIDD } & $1-5$ yıl & 65 & 4,423 & 0,548 & \multirow{3}{*}{0,474} & \multirow{3}{*}{0,623} \\
\hline & 6-14 yil & 95 & 4,444 & 0,539 & & \\
\hline & 15-üstü & 35 & 4,342 & 0,466 & & \\
\hline \multirow{3}{*}{ OATIYY } & $1-5$ y1l & 65 & 3,884 & 0,637 & \multirow{3}{*}{0,619} & \multirow{3}{*}{0,540} \\
\hline & 6-14 y1l & 95 & 3,984 & 0,529 & & \\
\hline & 15-üstü & 35 & 3,938 & 0,459 & & \\
\hline \multirow{3}{*}{ MGS } & $1-5$ yıl & 65 & 4,503 & 0,538 & \multirow{3}{*}{2,970} & \multirow{3}{*}{0,054} \\
\hline & 6-14 y1l & 95 & 4,434 & 0,477 & & \\
\hline & 15-üstü & 35 & 4,250 & 0,485 & & \\
\hline
\end{tabular}


Tablo 8 incelendiğinde öğretmenlerin özel alan yeterlik algılarının kıdemlerine göre farklılaşıp farklılaşmadığını belirlemek amacı ile yapılan analizler sonucunda;

İÖSPD, DBG; DGID, OATIYY ve MGS yeterlik alanlarına ilişkin ortalamalar arasındaki farklılığın kıdem yılı değişkenine göre anlamlı olmadığı görülmektedir. Buna göre İngilizce öğretmenlerinin kıdemlerine göre yeterlik alanlarının tümünde algılarının benzer olduğu söylenebilir.

\section{Dördüncü alt probleme İlişkin Bulgular}

Araştırmanın 4. alt problemine ilişkin bulgular elde edilirken verilere bağımsız gruplar için $t$-test'i yapılmıştır. Sonuçlar Tablo $9^{\prime}$ da sunulmuştur.

Tablo 9. Mezun Olunan Okul Türüne Göre Öğretmen Yeterlik Algılarının Karşılaştırılması

\begin{tabular}{|c|c|c|c|c|c|c|c|c|}
\hline Yeterlik Alanı & $\begin{array}{c}\text { Mezun } \\
\text { Olunan Okul }\end{array}$ & $\mathbf{N}$ & $\bar{x}$ & Ss & Sd & $t$ & $\mathrm{p}$ & Fark \\
\hline \multirow{2}{*}{ İÖSPD } & Eğitim fak. & 171 & 4,571 & 0,450 & \multirow{2}{*}{193} & \multirow{2}{*}{0,031} & \multirow{2}{*}{0,975} & \\
\hline & Diğer & 24 & 4,575 & 0,434 & & & & \\
\hline \multirow{2}{*}{ DBG } & Eğitim fak. & 171 & 4,145 & 0,529 & \multirow{2}{*}{193} & \multirow{2}{*}{0,021} & \multirow{2}{*}{0,983} & \\
\hline & Diğer & 24 & 4,142 & 0,674 & & & & \\
\hline \multirow{2}{*}{ DGİD } & Eğitim fak. & 171 & 4,450 & 0,517 & \multirow{2}{*}{193} & \multirow{2}{*}{2,210} & \multirow{2}{*}{$0,028^{*}$} & Ĕgt \\
\hline & Diğer & 24 & 4,197 & 0,570 & & & & lehine \\
\hline \multirow{2}{*}{ OATİY } & Eğitim fak. & 171 & 3,966 & 0,557 & \multirow{2}{*}{193} & \multirow{2}{*}{1,625} & \multirow{2}{*}{0,106} & \\
\hline & Diğer & 24 & 3,770 & 0,519 & & & & \\
\hline \multirow{2}{*}{ MGS } & Eğitim fak. & 171 & 4,421 & 0,509 & \multirow{2}{*}{193} & \multirow{2}{*}{0,244} & \multirow{2}{*}{0,808} & \\
\hline & Diğer & 24 & 4,447 & 0,483 & & & & \\
\hline
\end{tabular}

Tablo 9 incelendiğinde öğretmenlerin özel alan yeterliklerinin mezun oldukları okul türüne göre farklılaşıp farklılaşmadığını belirlemek amacı ile yapılan analizler sonucunda;

İÖSPD, DBG, OATIY, MGS yeterlik alanlarına ilişkin eğitim fakültesinden mezun olan öğretmenlerin ortalamaları ile diğer bölümlerden mezun olan öğretmenlerin ortalamaları arasındaki farkın anlamlı olmadığı görülmektedir. Buna göre eğitim fakültesi mezunu öğretmenler ile diğer bölümlerden mezun olan öğretmenler bu yeterlik alanlarında kendilerini benzer şekilde yeterli olarak düşünmektedirler.

DGID yeterlik alanına ilişkin eğitim fakültesinden mezun olan öğretmenlerin ortalamaları $(\bar{x}=4,450)$ ile diğer bölümlerden mezun olan öğretmenlerin ortalamaları $(\bar{x}=4,197)$ arasındaki farkın anlamlı olduğu görülmektedir. $\left(\mathrm{t}_{(193)}=2,210 ; \mathrm{p}<0.05\right)$. Bu farkın eğitim fakültesinden mezun olan öğretmenler lehinde anlamlı olduğu söylenebilir. Buna göre eğitim 
fakültesi mezunu öğretmenler DGİD yeterlik alanında kendilerini diğer bölümlerden mezun olan öğretmenlerden daha yeterli olarak düşünmektedirler. Güven ve Çakır (2012) yaptıkları çalışmada eğitim fakültesi mezunu öğretmenlerin hizmet öncesi eğitimlerinde oldukça fazla deneyim yaşadıklarını ve bu nedenle öz-yeterlik inançlarının yüksek olduğunu ifade etmiştir. Yapılan bu araştırmanın sonuçlarına göre hizmet öncesi dönemde eğitim fakültesinde verilen eğitimin neticesinde ölçme değerlendirme konusunda öğretmenlerin tecrübe edindikleri ve pratiklik kazandıkları söylenebilir. Bu nedenle eğitim fakültesi mezunları lehine DGID yeterlik alnında bir farklılık saptanmış olabilir.

\section{Beşinci Alt Probleme İlişkin Bulgular}

Araştırmanın 5. alt problemine ilişkin bulgular elde edilirken verilere bağımsız gruplar için t-test'i yapılmıştır. Sonuçlar Tablo 10'da sunulmuştur.

Tablo 10. Görev Yapılan Okul Türüne Göre Öğretmen Yeterlik Algılarının Karşılaştırılması

\begin{tabular}{|c|c|c|c|c|c|c|c|c|}
\hline Yeterlik Alanı & $\begin{array}{c}\text { Görev } \\
\text { Yapılan } \\
\text { Okul }\end{array}$ & $\mathbf{N}$ & $\bar{x}$ & Ss & Sd & $\mathbf{t}$ & $\mathrm{p}$ & Fark \\
\hline \multirow[t]{2}{*}{ İÖSPD } & Özel & 35 & 4,674 & 0,420 & 193 & 1,493 & 0,137 & \\
\hline & Devlet & 160 & 4,550 & 0,451 & & & & \\
\hline \multirow[t]{2}{*}{ DBG } & Özel & 35 & 4,404 & 0,456 & 193 & 3,160 & $0,002^{*}$ & Özel \\
\hline & Devlet & 160 & 4,088 & 0,550 & & & & lehine \\
\hline \multirow[t]{2}{*}{ DGİD } & Özel & 35 & 4,528 & 0,464 & 193 & 1,353 & 0,178 & \\
\hline & Devlet & 160 & 4,395 & 0,540 & & & & \\
\hline \multirow[t]{2}{*}{ OATİY } & Özel & 35 & 3,923 & 0,475 & 193 & 0,222 & 0,825 & \\
\hline & Devlet & 160 & 3,946 & 0,573 & & & & \\
\hline \multirow[t]{2}{*}{ MGS } & Özel & 35 & 4,378 & 0,515 & 193 & 0,591 & 0,555 & \\
\hline & Devlet & 160 & 4,434 & 0,503 & & & & \\
\hline
\end{tabular}

Tablo 10 incelendiğinde öğretmenlerin özel alan yeterlik algılarının görev yapmakta oldukları okul türüne göre farklılaşıp farklılaşmadığını belirlemek amacı ile yapılan analizler sonucunda;

İÖSPD, DGID, OATIY ve MGS yeterlik alanlarına ilişkin özel okulda çalışan öğretmenlerin ortalamaları ile devlet okulunda çalışan öğretmenlerin ortalamaları arasındaki farkın anlamlı olmadığı görülmektedir. Buna göre özel okul ve devlet okulunda çalışan öğretmenler bu yeterlik alanlarında kendilerini benzer şekilde yeterli olarak düşünmektedirler. 
DBG yeterlik alanına ilişkin özel okulda çalışan öğretmenlerin ortalamaları $(\bar{x}=4,40)$ ile devlet okulunda çalışan öğretmenlerin ortalamaları $(\bar{x}=4,08)$ arasındaki farkın anlamlı olduğu görülmektedir. $\left(t_{(193)}=3,160\right.$; $\mathrm{p}<0.05)$. Bu farkın özel okulda çalışan öğretmenler lehinde olduğu söylenebilir. Buna göre özel okulda çalışan öğretmenler DBG yeterlik alnında devlet okulunda çalışan öğretmenlerden kendilerini daha yeterli olarak düşünmektedirler.

Sünbül ve Arslan (2009) yaşanılan ya da çalışılan ortamın bireyin düşüncelerini ve algılamalarını etkileyebileceğini ifade etmiştir ve bu nedenle yapılan bu çalışmada öğretmenlerin çalıştığı okulların durumu ve imkânları onların yeterlik algılarında bir fark yaratmış olabilir.

\section{Altıncı Alt Probleme İlişkin Bulgular}

Araştırmanın 6. alt problemine ilişkin bulgular elde edilirken verilere bağımsız gruplar için t-test'i yapılmıştır; sonuçlar Tablo $11^{\prime}$ de sunulmuştur.

Tablo 11. Hizmet-içi Eğitim Alma Durumuna Göre Öğretmen Yeterlik Algılarının Karşılaştırılması

\begin{tabular}{|c|c|c|c|c|c|c|c|}
\hline Yeterlik Alanı & $\begin{array}{l}\text { Hizmetiçi } \\
\text { Eğt. }\end{array}$ & $\mathbf{N}$ & $\bar{x}$ & Ss & Sd & $\mathbf{t}$ & $\mathbf{p}$ \\
\hline \multirow[t]{2}{*}{ İÖSPD } & Alan & 132 & 4,610 & 0,41961 & 193 & 1,739 & 0,084 \\
\hline & Almayan & 63 & 4,492 & 0,49491 & & & \\
\hline \multirow[t]{2}{*}{ DBG } & Alan & 132 & 4,181 & 0,56762 & 193 & 1,360 & 0,175 \\
\hline & Almayan & 63 & 4,068 & 0,49875 & & & \\
\hline \multirow[t]{2}{*}{ DGİD } & Alan & 132 & 4,447 & 0,52788 & 193 & 1,060 & 0,290 \\
\hline & Almayan & 63 & 4,361 & 0,53086 & & & \\
\hline \multirow[t]{2}{*}{ OATİY } & Alan & 132 & 3,982 & 0,55076 & 193 & 1,444 & 0,150 \\
\hline & Almayan & 63 & 3,859 & 0,56178 & & & \\
\hline \multirow[t]{2}{*}{ MGS } & Alan & 132 & 4,454 & 0,51764 & 193 & 1,210 & 0,228 \\
\hline & Almayan & 63 & 4,361 & 0,47472 & & & \\
\hline
\end{tabular}

Tablo 11 incelendiğinde öğretmenlerin özel alan yeterlik algılarının hizmet-içi eğitim alıp almama durumuna göre farklılaşıp farklılaşmadığını belirlemek amacı ile yapılan analizler sonucunda,

IÖSPD, DBG, DGID, OATIY ve MGS yeterlik alanlarına ilişkin hizmet-içi eğitim alan öğretmenlerin ortalamaları ile hizmet-içi almayan öğretmenlerin ortalamaları arasındaki farkın anlamlı olmadığ görülmektedir. Buna göre hizmet-içi alan ve almayan öğretmenler yeterlik alanlarının tümünde kendilerini benzer şekilde yeterli olarak düşünmektedirler. 
Ortaçtepe (2006) yaptığı araştırmada öğretmenlerin aldıkları hizmet içi eğitim ile öz-yeterlik algıları arasında bir ilişki olmadığını saptamıştır. Bu durum, hizmet içi eğitim programlarının niteliği ve etkililiği ile ilgili olabilir. Ayrıca katılımcıların duyuşsal özelliklerine bağlı olabilir. Birçok hizmet içi eğitim seminerinde katılımcıların gönüllülüğünün esas alınmadığı düşünülürse seminerlerin etkililiği de bu doğrultuda etkilenmektedir. Saracaloğlu, Karasakaloğlu ve Gencel (2010) tarafından yapılan araştırmada ise öğretmenlerin öz yeterlik düzeylerinin hizmet içi eğitim alma durumuna göre farklılaştı̆̆ saptanmıştır.

\section{Tartışma, Sonuç ve Öneriler}

Bu araştırmada, ilköğretim İngilizce öğretmenlerinin öğretmenlik mesleği özel alan yeterliklerine ilişkin algılarının çeşitli değişkenlere göre değişkenlik gösterip göstermediği araştırılmıştır.

Araştırmanın birinci alt probleminin sonucu olarak İngilizce öğretmenlerinin öğretmenlik mesleği özel alan yeterliklerine ilişkin yeterlik algılarının oldukça yüksek olduğu bulunmuştur.

Araştırma bulguları incelendiğinde İÖSPD yeterlik alanında İngilizce öğretmenlerinin çoğunun bu konuda kendilerini yeterli gördükleri ortaya çıkmıştır. Öğretmen yeterlikleriyle ilgili yapılan diğer araştırmalar incelendiğinde öğretmenlerin öğretim sürecini planlama ve düzenleme boyutuyla ilgili yeterliliklerinin yüksek olduğu ortaya çıkmıştır Meşe, 2010; Eraslan-Keskinkılıç, 2010; Karaca,2004; Numanoğlu ve Bayır, 2009; Akpınar, 2004. Meşe (2010) ve Karaca (2004) tarafından yapılan çalışmalarda da öğretmenlerin öğretim sürecini planlamada kendilerini yeterli bulurken Çoşkun, Gelen ve Öztürk (2009) tarafından yapılan çalışmada kendilerinin yetersiz olduklarını düşündükleri ortaya çıkmıştır.

DBG yeterlik alanında da İngilizce öğretmenlerinin çoğunun bu konuda kendilerini yeterli gördükleri ortaya çıkmıştır. Demirel $(1989,1990)$ yabancı dil öğretmenlerinin yeterliklerini araştırdığı çalışmasında Türk ve yabancı İngilizce öğretmenlerinin meslek bilgisi yeterlikleri bağlamında öğrencilerin okuma, yazma, konuşma ve dinleme becerilerini geliştirmede Türk İngilizce öğretmenlerinin göstermeleri gereken yeterlikleri yabancı İngilizce öğretmenlerinden daha az gösterdikleri ancak bu farkın fazla olmamasının sevindirici olduğu belirtilmiştir. Yani, Türk öğretmenlerin meslek bilgisi yeterliklerinin yabancı öğretmenlerin meslek bilgisi yeterliklerinden farklı olmadığı ortaya çıkmıştır. 
DGID yeterlik alanında da İngilizce öğretmenlerinin çoğunun bu konuda kendilerinin yeterli gördükleri ortaya çıkmıştır. Koç'un (2010) yaptığı bir araştırma da ise din kültürü ve ahlak bilgisi öğretmenlerinin yeni ölçme değerlendirme yöntem ve tekniklerini kavrama, benimseme ve kullanmada kendilerini orta düzeyde yeterli olarak gördükleri anlaşılmaktadır.

OATIYY yeterlik alanında da İngilizce öğretmenlerinin çoğunun bu konuda kendilerini yeterli gördükleri ortaya çımıştır ancak öğretmenler beş yeterlik alanı arasından OATIY yeterlik alanında diğer alanlara göre kendilerini daha az yeterli algılamaktadırlar. OATIY yeterlik alanının aritmetik ortalamasına bakıldığında öğretmenlerin kendilerini en yetersiz olarak algıladıkları alanda bile oldukça yeterli gördükleri söylenebilir. Koç'un (2010) yaptığ çalışmanın sonucu da benzer olarak Din kültürü öğretmenlerinin okul aile ve toplumla ilişkiler boyutundaki yeterliklere sahip olma düzeylerine ilişkin ortalamalarının diğer boyutlara göre (kişisel ve mesleki değerler ve mesleki gelişim / öğrenciyi tanıma ve öğrenciyle ilişkiler) daha düşük olduğu göstermektedir. Numanoğlu ve Bayır'ın (2009) çalışmasında da Bilgisayar öğretmen adaylarının okul, aile ve toplum ilişkileri yeterlik alanının kazanılma durumuna ilişkin genel ortalama en düşük çıkmıştır.

İngilizce alnında MGS yeterlik alanında da İngilizce öğretmenlerinin çoğunun bu konuda kendilerinin yeterli gördükleri ortaya çıkmıştır. Yavuz'un (2007) çalışma sonuçları da bu çalışmanın sonuçlarıyla benzerlik göstermektedir. Yavuz (2007) İngilizce öğretmenleri üzerinde yürüttüğü araştırmasında öğretmenlerin mesleki alanda yaptığı çalışmalarla öğretmen yeterliklerinin ilişkili olduğunu; öğretmenlerin ne kadar çok etkinlik içinde bulunursa kendilerini o kadar daha verimli ve yeterli hissettiklerini belirtmiştir. Karacaoğlu (2008) tarafından yapılan çalışmada öğretmenlerin kendini geliştirme yeterlilik algılarının ortalamasına bakılarak öğretmenlerin kendilerini geliştirme konusunda çok yeterli gördükleri ortaya çıkmıştır. Saracaloğlu, Özşaker ve Varol'un (2012) yaptığı çalışmanın sonucunda mesleki yayınları takip eden beden eğitimi öğretmenlerinin etmeyen öğretmenlerden daha yüksek öz-yeterlik seviyesine sahip oldukları ortaya çıkmıştır.

Araştırmanın ikinci alt probleminin sonucu olarak İngilizce öğretmenlerinin özel alan yeterliklerine ilişkin yeterlik algılarında cinsiyet değişkenine göre yeterlik alanlarının ortalama puanları karşılaştırıldığında DBG ve OATIY yeterlik alanlarında erkek ve kadın öğretmenler arasında anlamlı bir farklılık olduğu görülmektedir. Kadın öğretmenlerin DBG ve OATIY alanlarında kendilerini erkek öğretmenlerden daha yeterli olarak 
algıladıkları tespit edilmiştir. Diğer yeterlik alanlarında erkek ve kadın öğretmenlerin yeterlik algılarının benzer olduğu tespit edilmiştir. İlgili literatürde öğretmen ve öğretmen adaylarının yeterlik algılarında anlamlı farklılık olmadığını ortaya koyan birçok çalışmanın Tschannen-Moran and Hoy, 2001; Taşar, 2012; Tunç-Yüksel, 2010; Güneş, 2011; Çoşkun, Özer ve Tiryaki, 2010; Dede, 2008; Coşkun, Gelen, Öztürk, 2009; Yılmaz, 2010; Küçükoğlu, 2012 yanında bazı araştırmalarda Sünbül ve Arslan, 2009; Çapri ve Çelikkaleli, 2008; Ekici, 2006 kadınlar lehine anlamlı bir farklılık olduğu ortaya konmuştur. Tunç Yüksel (2010) çalışmasında İngilizce öğretmenlerinin mesleki yeterlik algılarının cinsiyete göre değişmediğini bulurken; Sünbül ve Arslan'ın (2009) çalışmasında öğretmenlerin yeterlik puan ortalamalarında cinsiyete göre kadınlar lehine anlamlı bir farklılık olduğu saptanmıştır.

Araştırmanın üçüncü alt probleminin sonucu olarak İngilizce öğretmenlerinin özel alan yeterliklerine ilişkin yeterlik algılarında kıdem yılı değişkenine göre yeterlik alanlarının hiçbirinde anlamlı bir fark bulunmamıştır. İngilizce ve farklı branştan öğretmenlerin yeterlik algılarıyla ilgili yapılan araştırmalarda da benzer sonuçlara ulaşıldığı görülmektedir. Özlük, 2010; Güven, 2005; Tunç-Yüksel, 2010; Yılmaz ve Çokluk-Bökeoğlu, 2008; Üstüner, Demirtaş, Cömert vd, 2009. Güven (2005), Yılmaz ve Çokluk Bökeoğlu (2008) ve Tunç-Yüksel (2010) yaptıkları araştırmalarında mesleki deneyimin İngilizce öğretmenlerin yeterlik algısı üzerinde etkisi olmadığını bulunurken; Taşar'ın (2012) çalışmasında ise öğretmenlerin yeterlik algılarının hizmet yılı değişkenine göre ölçeğin kişisel ve mesleki değerler alt boyutunda 21 ve üstü, öğrenme ve öğretme süreci ve okul, aile ve toplum ilişkileri alt boyutunda ise 16-20 hizmet yılı aralığında olan öğretmenlerin lehine bir farklılığın olduğu saptanmıştır.

Araştırmanın dördüncü alt problemin sonucu olarak İngilizce öğretmenlerinin özel alan yeterliklerine ilişkin yeterlik algılarında İÖSPD, DBG, OATIY ve MGS yeterlik alanlarında mezun olunan okul türü değişkenine göre anlamlı bir fark bulunmazken; DGID yeterlik alanında anlamlı bir fark olduğu ortaya çıkmıştır. Bu fark eğitim fakültesinden mezun olan öğretmenler lehine anlamlıdır. Taşar'ın (2012) araştırmasının sonucunda da öğretmenlerin mesleki yeterlik algılarının mezun olunan okul türüne göre ölçeğin bütün boyutlarında eğitim fakültesi mezunu öğretmenler lehine farklılaştığı gözlemlenmiştir.

Araştırmanın beşinci alt probleminin sonucu olarak İngilizce öğretmenlerinin özel alan yeterliklerine ilişkin yeterlik algılarında İÖSPD, 
DGID, OATIYY ve MGS yeterlik alanlarında görev yaptıkları okul türü değişkenine göre anlamlı bir fark bulunmazken; DGB yeterlik alanında anlamlı bir fark olduğu ortaya çıkmıştır. Bu fark özel okullarda çalışan öğretmenler lehine anlamlıdır. Konuyla ilgili literatürde özel ve devlet okullarına ilişkin sadece bir araştırmaya rastlanılmıştır. Saracaloğlu, Özşaker ve Varol (2012) tarafından yapılan araştırmada beden eğitimi öğretmenlerinin öğretmenlik mesleği öz-yeterlik seviyeleri çeşitli değişkenlerle ilişki kurularak araştırılmıştır. Araştırma sonuçlarına göre özel okulda çalışan öğretmenlerin devlet okulunda çalışan öğretmenlerden daha yüksek öz-yeterlik seviyesine sahip oldukları ortaya çıkmıştır. Tam olmasa da benzer sayılabilecek bir araştırma Üstüner, Demirtaş, Cömert vd (2009) tarafından yapılmıştır. İlköğretim öğretmenlerinin öz-yeterlik algılarıyla ilgili yapılan araştırmada öğretmenlerin öz-yeterlik algılarının cinsiyet ve branşa göre değişmediği ancak görev yapılan okul türüne göre farklılaştığ1 sonucuna ulaşılmıştır. Farklılığın anadolu ve fen liselerinde çalışan öğretmenler lehine olduğu saptanmıştır.

Araştırmanın altıncı alt probleminin sonucu olarak İngilizce öğretmenlerinin özel alan yeterliklerine ilişkin yeterlik algılarında hizmet-içi eğitim alma değişkenine göre yeterlik alanlarının hiçbirinde anlamlı bir fark bulunmamıştır. Ancak yeterlik alanlarının ortalama puanları karşılaştırıldığında hizmet-içi eğitim alan öğretmenlerin almayan öğretmenlerden daha yüksek ortalamaya sahip oldukları görülmektedir. Konuyla ilgili olarak Jeong- Ah Lee (2009), Taşar (2012) ve Güven (2012) tarafından yapılan çalışmalarda da öğretmenlerin mesleki yeterlik algılarında hizmet-içi eğitimi alma değişkenine göre farklılaşma görülmemiştir.

\section{Öneriler}

$\mathrm{Bu}$ araştırmanın bulguları ışığında şu öneriler geliştirilebilir:

1. Araştırma bulgularına göre öğretmenlerin öğrencilerin konuşma ve dinleme becerilerini geliştirebilmelerine ilişkin yeterlik algılarının yazma ve okuma becerilerini geliştirebileceklerine olan algılarından daha düşüktür. Öğretmenlerin bu iki beceriyi geliştirebileceklerine olan algılarını yükseltilmesi için konuşma ve dinleme dersleri ayrı ders olarak öğrencilere verilmesi önerilebilir ve bu derslerin amacına uygun yapılabilmesi için okullarda dil laboratuvarların kurulup çeşitli dinleme ve konuşma etkinliklerinin sağliklı yapılabilmesi sağlanabilir. Böylelikle hem öğretmenlerin hem de öğrencilerin bu becerilere yönelik yeterliklerini artıracakları söylenebilir. 
2. Araştırma bulgularına göre DBG yeterlik alanında özel okulda çalışan öğretmenler devlet okulunda çalışan öğretmenlerden kendilerini daha yeterli algılamaktadır. Bu durumun özel okullarda dil becerilerini geliştirmeye yönelik etkinlikler içiren kitaplar kullanmasından ve okulların fiziki ve teknik yönden oldukça donanımlı olmasına bağlı olduğu düşünülebilir. Bu bağlamda devlet okullarında okul aile birliği devreye sokularak ya da sponsorlar bulunarak teknik donanım (projeksiyon, bilgisayar, internet ağı, vb.) yeterli seviyeye getirilebilirse yukarıda belirtildiği gibi DBG yeterlik alanına yönelik çeşitli ve değişik etkinliklerin sürekli yapılması sağlanabilir.

3. Araştırma bulgularına göre öğretmenler OATIYY yeterlik alanında diğer alanlara göre kendilerini daha az yeterli algilamaktadırlar. Öğretmenlere bu eksikliklerinin giderilmesinde gerek hizmet-içi eğitim kursları olarak gerekse okullarda rehberlik öğretmenlerinden ya da uzmanlar tarafından düzenlenen seminerlere katılımlarının sağlanarak destek verilebilir. Hatta okul aile birliklerinin düzenleyeceği etkinliklerle öğretmen, okul, aile ve dolayısıyla toplum ilişkileri geliştirilebilir.

4. Araştırma bulgularına göre eğitim fakültesinden mezun öğretmenler DGID yeterlik alanında kendilerini diğer fakülte mezunlarından daha yeterli algılamaktadırlar. Bu durumun eğitim fakültesi dışındaki fakültelerden mezun olan öğretmenlerin ölçme değerlendirme yöntem ve teknikleri, değerlendirmeleri gibi konularda hizmet öncesi dönemde eksik yetiştirilmiş olmasından kaynaklanabilir. Diğer fakülte mezunlarının hizmet-içi eğitim seminerleri aracılı̆̆ıyla ölçme değerlendirme konusunda yeterliklerinin artırılması yoluna gidilebilir.

5. Araştırma bulgularına göre kadın öğretmenler DBG ve OAİTY yeterlik alanlarında kendilerini erkek öğretmenlerden daha yeterli algılamaktadırlar. Aslında bu durum bir nevi yaradılış gereği erkeklerin kadınlardan farklı olarak sahip oldukları özelliklere bağlanabilir. $\mathrm{Bu}$ nedenle öğretmen yeterlik algılarındaki bu farklılaşmanın kaynağını derinlemesine araştırmak için nitel çalışmalar yapılabilir. Ayrıca erkek öğretmenlerin DBG ve OAİTY yeterlik alanına ait eksikliklerini geliştirmeye yönelik etkinlikler ve eğitimler düzenlenebilir. 


\section{Kaynakça}

Ah Lee, J. (2009). Teachers Sense of Efficacy in Teaching English, Perceived English Language Proficiency, and Attitudes Towards the English Language: A Case of Korean Public Elementary School Teachers. Dissertation, The Ohio State University, Colombus, OH.

Akpınar, B. (2004). Öğretmen Adaylarının Gözüyle Sınıf Öğretmenlerinin Yeterlikleri. XIII. Ulusal Ĕ̆itim Bilimleri Kurultayı, 6-9 Temmuz, İnönü Üniversitesi Eğitim Fakültesi, Malatya.

Baykara, K. (2011). Öğretmen Adaylarının Bilişötesi Öğrenme Stratejileri ile Öğretmen Yeterlik Algıları Üzerine Bir Çalışma. Hacettepe Üniversitesi Eğitim Fakültesi Dergisi, 40, 80-92.

Beltekin, N. (2010). Öğretmen Yeterlikleri. Uluslararası Öğretmen Yetiştirme Politikalarn ve Sorunlar Sempozyumu II, 16-18 Mayıs, Hacettepe Üniversitesi, Beytepe-Ankara, 233-241.

Bilir, A. (2011). Türkiye'de Öğretmen Yetiştirmenin Tarihsel Evrimi ve İstihdam Politikaları. Ankara Üniversitesi Eğitim Bilimleri Fakültesi Dergisi, 44 (2), 223-246.

Bingöl M. ve Tuba, E. (2010). Bilişim Teknolojileri Öğretmenlerinin Özel Alan Yeterlikleri Açısından Kendilerini Değerlendirmeleri: İzmir İli Örneği. Yayınlanmamış Yüksek Lisans Tezi, Ege Üniversitesi Fen Bilimleri Enstitüsü, İzmir.

Büyükduman, F. İ. (2006). İngilizce Öğretmen Adaylarının İngilizce ve Öğretmenlik Becerilerine İlişkin Öz-Yeterlik İnançları ve Arasındaki İlişki. Yayımlanmamış Yüksek Lisans Tezi, Yıldız Teknik Üniversitesi Sosyal Bilimler Enstitüsü, İstanbul.

Coşkun, E., Gelen, İ. ve Öztürk, E. P. (2009). Türkçe Öğretmeni Adaylarının Öğretimi Planlama, Uygulama ve Değerlendirme Yeterlik Algıları. Mustafa Kemal Üniversitesi Sosyal Bilimler Enstitüsü Dergisi, 6 (12), 140-163.

Coşkun, Eyüp, Özer, B. ve Tiryaki, E. N. (2010). Türkçe Öğretmeni Adaylarının Özel Alan Yeterlik Algılarının Değerlendirilmesi. Dokuz Eylül Üniversitesi Buca Ĕ̆itim Fakültesi Dergisi, 27, 123-136.

Çakır, Ö. ve Alıcı, D. (2009). Seeing Self as Others See You: Variability in Self-Efficacy Ratings in Student Teaching. Teachers and Teaching: Theory and Practice, 15 (5), 541-561.

Çapri, B. ve Çelikkaleli, Ö. (2008). Öğretmen Adaylarının Öğretmenliğe İlişkin Tutum ve Mesleki Yeterlik İnançlarının Cinsiyet, Program ve 
Fakültelerine Göre İncelenmesi. İnönü Üniversitesi Eğitim Fakültesi Dergisi, 9(15), 33-53.

Dede, Y. (2008). Matematik Öğretmenlerinin Öğretimlerine Yönelik ÖzYeterlik İnançları. Türk Ĕ̆itim Bilimleri Dergisi, 6(4), 741-757.

Demirel, Ö. (1989). Yabancı Dil Öğretmenlerinin Yeterlikleri. Hacettepe Üniversitesi Eğitim Fakültesi Dergisi, 4, 5-26.

Demirel, Ö. (1991). Türkiye'de Yabancı Dil Öğretmeni Yetiştirmede Karşılaşılan Güçlükler. Hacettepe Üniversitesi Eğitim Fakültesi Dergisi, $6,25-39$.

Ekici, G. (2006). Meslek Lisesi Öğretmenlerinin Öğretmen Öz- Yeterlik İnançları Üzerine Bir Araştırma. Eurasian Journal of Educational Research, 24, 87-96.

Eraslan Keskinkılıç, F. (2010). İlköğretim Bilişim Teknolojileri Öğretmenlerinin Yeterliklerinin Okul Müdürlerinin Görüşlerine Göre Değerlendirilmesi. Uluslararası Öğretmen Yetiştirme Politikaları ve Sorunları Sempozyumu II, 16-18 Mayıs, Hacettepe Üniversitesi, Beytepe-Ankara, 116-125.

Güneş, S. (2011). Kimya Öğretmen Adaylarının Özel Alan Yeterliklerinin Araştırılması. Yayınlanmamış Yüksek Lisans Tezi, Gazi Üniversitesi Eğitim Bilimleri Enstitüsü, Ankara.

Güven, S. (2005). The Profile and The Perception of Professional Competencies of the First Stage State Primary School EFL Teachers. Yayınlanmamış Yüksek Lisans Tezi, Mersin Üniversitesi Sosyal Bilimler Enstitüsü, Mersin.

Güven, S. ve Çakır, Ö. (2012). A Study on Primary School English Teachers' Self Efficacy Beliefs. Eğitim ve Bilim, 37(163), 43-52.

Karaca, E. (2004). Öğretmen Adaylarının Planlama ve Öğretim Süreci Yeterliklerine İlişkin Algıları. XIII. Ulusal Eğitim Bilimleri Kurultayı, 6-9 Temmuz, İnönü Üniversitesi Eğitim Fakültesi, Malatya.

Karaca, E. (2008). Eğitimde Kalite Arayışları ve Eğitim Fakültelerinin Yeniden Yapılandırılması. Dumlupınar Üniversitesi Sosyal Bilimler Dergisi, 21, 61-77.

Karacaoğlu, Ö. C. (2008). Öğretmenlerin Yeterlik Algıları. Yüzüncü Yıl Üniversitesi, Eğitim Fakültesi Dergisi, 5(1), 70-97.

Karasar, N. (2005). Bilimsel Araştırma Yöntemi. Nobel Yayın Dağıtım, Ankara.

Kline, P. (1994). An Easy Guide to Factor Analysis. New York: Routledge. 
Koç, A. (2010). Din Kültür ve Ahlak Bilgisi Öğretmenlerinin Yeterlikleri. Değerler Eğitimi Dergisi, 8 (19), 107-149.

Küçükoğlu, H. (2013). The Interface Between EFL Teachers' Self Efficacy Concerning Critical Reading Comprehension and Some Select Variables. Procedia Social and Behavioral Sciences, 70, 1646-1650.

MEB, (2002), Öğretmen Yeterliklerinin Belirlenmesi http://otmg.meb.gov.tr/ Yayin.html (Erişim Tarihi: 03.01.2012).

MEB, (2006). TEDP Öğretmen Eğitimi Bileşeni Öğretmenlik Mesleği Genel Yeterlikleri. http://otmg.meb.gov.tr/belgeler/otmg/Yeterlikler.pdf (Erişim Tarihi: 11 Mayıs 2010).

MEB, (2008). Öğretmen Yeterlikleri Öğretmenlik Mesleği Genel ve Özel Alan Yeterlikleri. http://otmg.meb.gov.tr/alaningilizce.html (Erişim Tarihi: 11 Mayıs 2010).

Numanoğlu, G. ve Bayır, Ş. (2009). Bilgisayar Öğretmen Adaylarının Öğretmenlik Mesleği Genel Yeterliklerine İlişkin Görüşleri. Ahi Evran Üniversitesi Kırşehir Eğitim Fakültesi Dergisi, 10 (1),197-212.

Ortaçtepe, D. (2006). The relationship between teacher efficacy and professional development within the scope of an in service teacher education program. Yayınlanmamış Yüksek Lisans Tezi, Boğaziçi Üniversitesi Sosyal Bilimler Enstitüsü, İstanbul.

Özel Alan Yeterlikleri Gelişim Raporu (2008); http://otmg.meb.gov.tr/YetOzel.html (Erişim Tarihi: 18.10.2012).

Özlük, Y. Ö. (2010). Türkçe Öğretmenlerini Özel Alan Yeterliklerine İlişkin Bir Araştırma (Kırıkkale İli Örneği). Yayınlanmamış Yüksek Lisans Tezi, Kırıkkale Üniversitesi Sosyal Bilimler Enstitüsü, Kırıkkale.

Saracaloğlu, A. S., Karasakaloğlu, N. ve Gencel, İ. E. (2010). Türkçe Öğretmenlerinin Öz yeterlik Düzeylerinin Çeşitli Değişkenlere Göre İncelenmesi. Elektronik Sosyal Bilimler Dergisi, 9(33), 265-283.

Saracaloğlu, A. S., Özşaker, M. ve Varol, R. (2012). Investigation of Professional Self Sufficiency Levels of Physical Education and Sports Teachers. International Journal of New Trends in Arts, Sports and Science Education, 1(3), 63-71.

Seferoğlu, S. S. (2004). Öğretmen Adaylarının Öğretmen Yeterlikleri Açısından Kendilerini Değerlendirmeleri. Hacettepe Üniversitesi Ĕğitim Fakültesi Dergisi, 26, 131-140.

Sünbül, A. M. ve Arslan, C. (2009). Öğretmen Yeterlik Ölçeğinin Geliştirilmesi ve Bir Araştırma Örneği. tef.selcuk.edu.tr/salan/ sunbul/f/f17.doc (Erişim Tarihi: 02.10.2012). 
Taşar, H. H. (2012). İlköğretim Okullarında Çalışan Öğretmenlerin Mesleki Yeterlik Algılarının İncelenmesi (Adıyaman İli Örneği). Verimlilik Dergisi, 4, 67-77.

Tschannen Moran, M. ve Woolfolk Hoy, A. (2001). Teacher Efficacy: Capturing An Elusive Construct. Teaching and Teacher Education, 17, 783-805.

Tunç Yüksel, B. (2010). Teacher Efficacy Beliefs of Turkish EFL Teachers: A Study With Turkish EFL Teachers Working at State Primary Schools. Yayınlanmamış Yüksek Lisans Tezi, Anadolu Üniversitesi Eğitim Bilimleri Fakültesi, Eskişehir.

Uygur, M. (2010). İngiliz Dili Ĕ̆itimi Anabilim Dalı Lisans Öğrencilerinin ÖzYeterlik Algılarının Farklı Değişkenlere Göre İncelenmesi. Yayınlanmamış Yüksek Lisans Tezi, Mersin Üniversitesi Sosyal Bilimler Enstitüsü, Mersin.

Üstüner, M., Demirtaş, H., Cömert, M. ve Özer, N. (2009). Ortaöğretim Öğretmenlerinin Öz-Yeterlik Algıları. Mehmet Akif Ersoy Üniversitesi Ĕ̆itim Fakültesi Dergisi, 9(17), 1-16.

Yavuz, Ş. (2007). Socio-Demographic Predictors of EFL Teacher Efficacy. Journal of Language and Linguistic Studies, 3(2), 304-324.

Yeşilyurt, E. (2011). Öğretmen Adaylarının Öğretmenlik Mesleğinin Genel Yeterliklerine Yönelik Yeterlik Algıları. Türk Ĕgitim Bilimleri Dergisi, 9(1), 71-100.

Yllmaz, İ. (2010). Türkçe Öğretmeni Adaylarının Özel Alan ve Öz Yeterlik Algıları. Yayınlanmamış Yüksek Lisans Tezi, Atatürk Üniversitesi Sosyal Bilimler Enstitüsü, Erzurum.

Yılmaz, K. ve Bökeoğlu, Ö. Ç. (2008). İlköğretim Okulu Öğretmenlerinin Yeterlik İnançları. Ankara Üniversitesi Eğitim Bilimleri Fakültesi Dergisi, 41(2), 143-167.

Zehir Topkaya, E. ve Yavuz, A. (2011). Democratic Values Perceptions of and Teacher Self Efficacy Perceptions: A Case of Pre Service English Language Teachers in Turkey. Australian Journal of Teacher Education, $38(8), 32-49$. 